\title{
Anti-EU Backlash from Below or Above? Public Opinion in Central and Eastern Europe Prior to the 2015 Migration Crisis
}

DOI: $10.5613 /$ rzs.51.3.1

UDC 316.654(4-11/191.2):314.15

$314.15(4) " 2013 / 2015 "$

$327(4)(4-6 E U)$

Original Research Article

Received: 14 June 2021

\begin{abstract}
Nikola PETROVIĆ (DD https://orcid.org/0000-0002-0308-521X
Institute for Social Research in Zagreb - IDIZ, Croatia

nikola@idi.hr
\end{abstract}

Marko MRAKOVČIĆ (D) https://orcid.org/0000-0002-4919-0277

Faculty of Law, University of Rijeka, Croatia

mmrakovcic@pravri.hr

Filip FILA (D) https://orcid.org/0000-0002-9127-3324

Institute for Social Research in Zagreb - IDIZ, Croatia

filip@idi.hr

\section{ABSTRACT}

Relations between Brussels and Central and Eastern Europe (CEE) worsened during and after the 2015 migration crisis. In order to see to what extent CEE citizens contributed to and/or resonated with this new state of affairs, this paper investigates public opinion before the migration crisis in seven CEE EU Member States. We inquire whether the main issues of the rift (CEE political elites' opposition to following EU decisions and immigration and their emphasis on sovereignism, nationalism, Christian Europe and historical traumas) could also be traced to public stances towards these issues before the migration crisis. We used the ISSP National Identity module conducted in 2013 and 2014 in the Czech Republic, Estonia, Croatia, Hungary, Lithuania, Latvia and Slovenia. The results show that opposition to EU supranationalism was not linked to ethnic nationalism and religious identity (except in Hungary). Contrary to political elites, who emphasised the cultural threat posed by migration, public opinion was more concerned with the economic threat. Moreover, the perception of cultural threat was not linked to opposing EU supranationalism in any of the countries. However, particularly support for sovereignism (in almost all the countries), but also pride in national history (in some countries) correlated negatively with support for EU supranationalism. The results suggest that political elites can bypass public opinion to construct an anti-EU climate, however not out of thin air. The conditions for such a process were present in Hungary 
with its emerging transnational cleavage, which shows the importance of cleavages in studying Euroscepticism.

Key words: Euroscepticism, Central and Eastern Europe, public attitudes, national identity, migration

\section{INTRODUCTION}

Relations between Brussels and Central and Eastern European (CEE) Member States worsened during and after the 2015 migration crisis. The contention culminated as Visegrád Group states (Hungary, Slovakia, Czech Republic and Poland) rejected the plan for mandatory migrant quotas in September 2015. That the contention had spread to other post-socialist EU Member States was evident from a letter to the European Commission (EC) signed by the Ministers of the Interior of Visegrád states, as well as those of Slovenia, Estonia and Latvia in June 2020. In the letter, they reiterated "strong objection to mandatory relocation of asylum seekers and migrants in any shape or form" (Hamáček et al., 2020). But migration has not been the only issue of contention.

The 2010s in CEE were shaped by illiberal turns in Hungary and Poland, led by Eurosceptic ${ }^{1}$ Fidesz and PiS, respectively. The rise of centrist populists in the Czech Republic (ANO) and Slovakia (OL'aNO) marked the 2010s and particularly the beginning of the 2020s when these anti-establishment parties led coalition governments. In Slovenia, the newly formed government of Janez Janša followed the lead of Hungarian Prime Minister Viktor Orbán's Eurosceptic in 2020. Although at the time of signing of the letter to the EC both Latvia and Estonia were led by Prime Ministers from more (Unity in Latvia) or less (Estonian Centre Party) pro-European parties, both Ministers of the Interior belonged to more right-wing, Eurosceptic parties in coalition governments. Croatia and Lithuania were, on the other hand, led by strongly pro-European coalition governments and Lithuania experienced a notable decline of Eurosceptic forces. However, in Croatia, the radical right and Eurosceptic Homeland Movement has been challenging the dominance of the centre-right Croatian Democratic Union (HDZ) since 2019.

The developments of recent years indicate that, regardless of their similar historical backgrounds, various CEE Member States differ in their relations towards the EU (Styczyńska, 2017). Despite this, the growth of right-wing Euroscepticism has been apparent all over the region. Right-wing authoritarianism, as well as new contentious relations towards the EU in some of the CEE EU Member States, are

Euroscepticism of CEE parties was estimated by EU position scores from the Chapel Hill Expert Survey 2019 (Bakker et al., 2020). 
described as a result of "intellectual, ideological, and organizational innovations of a new authoritarian elite" in which a particularly prominent role is played by Orbán (Enyedi, 2020: 364). In 2016, Orbán organised a referendum on migrant quotas where $98 \%$ of voters rejected the proposition according to which the European Union would "be able to mandate the obligatory resettlement of non-Hungarian citizens into Hungary". Although the referendum was invalid due to turnout being lower than $50 \%$, Fidesz-led campaigns were successful in politicising the issue of migration and promoting anti-immigrant attitudes (Bíró-Nagy, 2021).

In order to see to what extent $C E E$ citizens contributed to and/or resonated with this new state of affairs, this paper investigates public opinion in seven CEE EU Member States before the migration crisis. The key question which emerged during and after the crisis is whether the EU could impose its decisions on EU Member States. To answer it, we use the International Social Survey Programme National Identity module (ISSP, 2015) conducted in 2013 and 2014 (pre-crisis), as it asks not only this particular question measuring the level of support for EU supranationalism but also a string of questions related to various issues that became the main talking points in terms of the relations between Brussels elites and Eurosceptic CEE elites. Previous research has analysed attitudes of voters in CEE after the migration crisis (2016) and has shown that anti-immigration and anti-EU attitudes have a positive effect on voting for radical-right populist parties, such as Fidesz and Estonian EKRE (Santana, Zagórski and Rama, 2020). However, a comparison of public opinion in CEE before the migration crisis regarding their support for EU decisions is largely absent. This comparison can provide a general answer to whether the public's sociodemographic characteristics, aspects of identification and social attitudes explained opposition to EU supranationalism before these issues were politicised in CEE. Moreover, comparing the public and the elites can help discern whether the elites' positions and actions towards the EU were grounded in prevailing public opinions or not. On a wider scale, it can help to understand the background of the rift between Brussels and CEE.

\section{THEORETICAL-CONCEPTUAL FRAMEWORK}

Political elites are often crucial in shaping public opinion and increasing support for ethnic intolerance and authoritarianism (for research in post-socialist countries see Sekulić, Massey and Hodson, 2006; Lavrič and Bieber, 2021). Likewise, it could be argued that Orbán and PiS leader Jarosław Kaczyński were the most prominent actors of the illiberal and authoritarian turn in CEE. As prominent CEE experts Zielonka and Rupnik argued (2020: 1074): "Voters in Central and Eastern Europe supported liberal policies and politicians for many years, so it is difficult 
to claim that this region is particularly prone to authoritarianism and xenophobia". Orbán and Kaczyński were also heavily involved in constructing the increase in refugees coming from war-torn countries as a civilisational clash and a full-scale crisis of relations within the EU. ${ }^{2}$ Hooghe and Marks (2018: 117) showed that party salience on immigration in 2010 was lower in CEE than in Western and Southern Europe. However, the migration crisis narrative allowed some CEE political actors to present themselves as protectors of their nations against migration from the East and centralisation from Brussels, while they were trying to take a firmer grip on the national judiciary and media (Vachudova, 2020).

Largely due to their ideological entrepreneurship and Brussels' initiatives and responses, several topics of the previous decade have been often presented as insurmountable differences between Western and Eastern Europe. Orbán (2020) summed this up in a speech, as he inaugurated a monument commemorating the Treaty of Trianon:

"Western Europe has renounced ... the spiritual energy of national culture. In other words, it has renounced Christian Europe. In place of this it is experimenting with a godless universe, with the rainbow reshaping of families, with migration and with open societies".

Four key elements of such CEE Eurosceptic narratives of the 2010s can be singled out. First, an emphasis on national interests instead of EU supranationalism, to the point of talking about a return to greater national sovereignty. Second, a refusal to make CEE countries immigrant and multicultural societies as happened in Western Europe. ${ }^{3}$ Third, the emphasis on the Christian character of both CEE nations and Europe as a whole, exemplified in the expression "Christian Europe" often used by Orbán. Fourth, strong historical narratives of national pride and Western betrayal, exemplified particularly by Orbán's insistence on the historical role of Hungary as a Christian bulwark and evocation of the Trianon trauma (see Petrović, 2019).

In their pursuit of general explanations of public support for European integration, Hobolt and de Vries (2016) found three main ones: (1) utilitarian approach (focusing on the benefits of European integration, with those more well-off and more

2 Every crisis is, in a way, socially constructed. By referring to the increase in refugees and migrants coming to the EU in 2015 as a "migration crisis" we do not wish to imply that this was a particularly shocking event in and of itself. Rather it could be claimed that political elites i.e., the new authoritarian CEE elite, were involved in framing it as such.

3 During and after the migration crisis, the issue of immigration in CEE was framed mainly as a cultural threat. However, due to the importance of the perception of both the economic and cultural threats regarding immigration, we analyse both dimensions, although separately (see Bandelj and Gibson, 2020). 
educated showing higher support for the EU), (2) identity approach (focusing on issues of national identity and national pride, with those more attached to their nations and more proud of their nations being more Eurosceptic) and (3) cue-taking approach (focusing on cues or proxies, such as political parties which help citizens form their opinion). The utilitarian aspect has not been central in the post-2015 Eurosceptic narratives in CEE, but we test it for each country. Aspects of national identity, however, have been prominent in those narratives; thus, we explore their effects on attitudes towards the EU. The third, cue-taking approach, informs our very research question: we inquire whether, prior to the onset of the CEE-Brussels rift, themes at the centre of the rift had any influence on the public opinion towards EU supranationalism (i.e., transferring sovereignty to EU institutions, see Díez Medrano, 2020). If the answer is yes, that means that the cues the Eurosceptic political parties and figures pushed already had some support "from below".

As a precursory note, we point out that Eurosceptic CEE themes that have emerged after 2015 are not necessarily region-specific, as the whole of the EU can be understood as being transformed by a new transnational cleavage. The focal point of this cleavage is "the defence of national political, social, and economic ways of life against external actors who penetrate the state by migrating, exchanging goods, or exerting rule" (Hooghe and Marks, 2018: 2). The definition broadly articulates the concept of sovereignism, whose influence on stances towards EU supranationalism is another relationship we investigate. In contrast to Western Europe, the transnational cleavage in CEE is more recent and can be analysed more clearly after the end of the accession process. However, transnational-national cleavage was more politicised in some of the analysed CEE countries than in others. In Croatia and Baltic countries, this cleavage was and still is moderated by what the majority of the elites see as the geopolitical necessity of joining and belonging to the West, i.e., the EU, and escaping from Serbian or Russian dominance. Czech politics were shaped by a socioeconomic cleavage (Hloušek and Kopeček, 2008). Until quite recently "the EU has not been an important issue of the inter-party competition line/cleavage in Slovenia" (Krašovec and Batrićević, 2020). On the other hand, Hungary stood out with a cleavage between more transnationally oriented liberals and socialists and more nationally oriented conservatives, drawing on a historical cleavage between traditionalists and Westernisers (Márkus, 1999). Consequently, it is not surprising that Orbán was again at the forefront of the rise of transnational-national cleavage, for instance in his 2011 European Parliament speech he "steadily emphasised that he was firmly resolved to defend the 'Hungarian national interest' at all times” (Arató and Koller, 2018: 91).

Next, we examine the closely connected concept of nationalism and its two most explored expressions: ethnic and civic (see Shulman, 2002; Janmaat 2006). 
The types of nationalism are measured with multiple items, which often form separate dimensions. Reeskens and Hooghe used the national identity ISSP module data grouped together and confirmed dichotomous ethnic-civic structure (2010). However, they also used it in various national contexts and concluded that ethnic and civic nationalism "are not being measured cross-nationally equivalent across nations" (2010: 593). Our analysis of CEE Member States confirmed this because, in some countries, the factor analysis produced different factor structures. Most notably, and highly indicative for other results that will be presented later, in Croatia there was only one factor containing variables representing both the ethnic and civic dimensions of identity. In the Croatian case, this could indicate a lack of differentiation regarding types of national identity, which could be the result of strong national cohesion forged by the Croatian War of Independence in the 1990s and its consequences. In Hungary, respect for Hungarian political institutions and laws belonged to quasi-ethnic citizenship, because Fidesz voters supported this statement more than left opposition voters, who were probably concerned about Fidesz's state capture. Aspects of ethnic and civic nationalism are often interpreted by respondents according to national contexts and not exclusively as part of firm theoretical concepts. Therefore, in order to see how national contexts influence the support or resistance to EU supranationalism, we opted for single variables.

We also inquire whether the topics related to the EU accession process had influenced citizens' attitudes towards EU supranationalism. The topic of protectionism i.e., the idea of protecting the national economy, marked the accession process. It encompassed an unfavourable trade balance for CEE countries and securing a transition period during which EU citizens would not be able to buy agricultural land in CEE countries (Vachudova, 2005). CEE EU Member States were also shaped by different trajectories when joining the EU. All of the analysed countries joined the EU in 2004, except Croatia. However, there were considerable differences even within this group. Lithuania and Latvia had more protracted negotiations "as they did not satisfy the Copenhagen economic criteria" (Vachudova, 2005: 158). Croatia had a unique journey to Europe compared to other CEE member states (Pauković and Raos, 2015). It joined the EU in 2013 after a long and difficult process, during which its accession was conditioned by full cooperation with the Hague war crimes tribunal. This eventually shook the foundations of Croatian European identity. In 2011, the Hague tribunal issued a first-instance verdict, sentencing Ante Gotovina, who was considered a national war hero, to a long-term prison sentence. At that point, trends reversed and opinion polls immediately showed that the majority of Croats would vote against EU membership (Bago, 2011). 


\section{AIMS AND HYPOTHESES}

This paper aims to investigate to what extent topics related to the transnational cleavage and CEE Eurosceptic narratives after the migration crisis determined the attitudes of citizens of Central and Eastern European countries towards EU supranationalism before the crisis. Our main hypothesis $(\mathrm{HO})$ is that no topics imposed by Eurosceptic political elites after 2015 were important for citizens' attitudes just before the onset of the crisis. Based on theoretical and empirical insights, several additional hypotheses were formulated. If support for themes related to the cleavage and Eurosceptic narratives existed among citizens, resisting the European Union should correlate positively with the following:

$\mathrm{H} 1$ : ethnic aspects of national identity

$\mathrm{H}$ 2: nationalism

H3: pride in national history

H4: protectionism

H5: sovereignism

H6: anti-immigrant attitudes

\section{DATA AND METHODS}

The data used in the analysis are from the National Identity III module of the 2013 ISSP dataset (ISSP, 2015). The sample comprised the citizens of investigated CEE countries. The countries are the Czech Republic (CZ), Estonia (EE), Croatia (HR), Hungary (HU), Lithuania (LIT), Latvia (LV), Slovenia (SI). ${ }^{4}$ Data were weighted with the supplied dataset weight ('WEIGHT'). Due to different sampling techniques in different countries, a weighing variable had to be used in order to correct sampling bias. ${ }^{5}$ Sample sizes were as follows (for additional data on survey methodology and samples see Joye and Sapin, 2016):

$4 \quad$ Poland was not included due to not being present in the ISSP dataset, while Slovakia had missing answers on variables concerning attitudes towards the EU and was therefore omitted.

5 "Each individual in the sample is assigned a weight to reflect the extent to which he or she would occur in repeated sampling from the population using the given sampling design" (Zou, Lloyd and Baumbusch, 2019: 6). 
Table 1. Sample sizes in researched countries ${ }^{6}$.

\begin{tabular}{cccccccc}
\hline & CZ & EE & HR & HU & LIT & LV & SI \\
\hline $\mathbf{N}$ & 1909 & 1009 & 1000 & 1007 & 1194 & 1000 & 1010 \\
\hline
\end{tabular}

\subsection{Survey measures}

The chosen ISSP module contains several variables pertaining to attitudes towards the EU. We chose a single dependent variable that best represents "resistance to Brussels' decisions". Question 18 provided the best wording of such a sentiment, albeit in the direction opposite to resistance: [COUNTRY] should follow [European Union] decisions, even if it does not agree with them. The scale ranged from 1 (agree strongly) to 5 (disagree strongly).

As for independent variables, we used two sets: sociodemographic ones and variables measuring respondents' identification and attitudes. Notably, we opted for single variables as representatives of relevant concepts instead of scales due to the thematic accents we wanted to investigate. Sociodemographic variables were: sex, age, highest completed education level, attendance of religious services, top-bottom self-placement ${ }^{7}$, voting in previous elections and urban vs. rural residence. Other explanatory variables were derived from the additional hypotheses.

The first couple of variables straightforwardly measure identification with a country and Europe: (1) How close do you feel to your country? (2) How close do you feel to Europe?

Four variables representing different aspects of How important for being truly (NATIONALITY) is were chosen. For civic nationalism, we selected: (1) To have (country nationality) citizenship; (2) To respect (country nationality) political institutions and laws. For ethnic nationalism, we selected: (1) To have (country nationality) ancestry; (2) To be a (country dominate) ${ }^{8}$ religion. The last question was also a proxy for the issue of Christian Europe.

From aspects of national pride, we choose two variables: (1) the question How proud are you of [COUNTRY]'s history? is a proxy for the issue of historical nar-

6 All samples are considerably smaller than the Czech one, but the minimum achieved sample size $(\mathrm{N}=1000)$ suffices for the statistical analysis carried out.

7 The top-bottom self-placement variable encompasses a broader estimate of one's position on the social ladder compared to others (1-lowest; 10-highest).

8 In Croatia, Slovenia and Lithuania, which are predominantly Catholic, respondents were asked: "How important do you think is to be a Catholic?" and in other analysed countries: "How important do you think is to be a Christian?" 
ratives emphasising glorious national past; (2) the question How proud are you of [COUNTRY]'s social security system? indirectly measures aspects of material well-being.

Attitudes toward immigration are measured by the following: 1) Immigrants are generally good for [COUNTRY'S] economy; (2) Immigrants take jobs away from people who were born in [COUNTRY]; (3) Immigrants improve [COUNTRY'S NATIONALITY] society by bringing new ideas and cultures (4) [COUNTRY's] culture is generally undermined by immigrants.

Nationalism is measured by the statement similar to the classical nationalist expression of "My country, right or wrong": (1) People should support their country even if the country is in the wrong; and (2) The world would be a better place if [COUNTRY NATIONALITY] acknowledged [COUNTRY's] shortcomings.

Attitudes towards sovereignism are measured by the following statements: (1) In general, (COUNTRY) should follow its own interests, even if this leads to conflicts; (2) International organisations are taking away too much power from the [COUNTRY NATIONALITY] government.

We also included two variables related to protectionism. A proxy for the problem of unfavourable trade balance is the statement: [COUNTRY] should limit the import of foreign products in order to protect its national economy. For the limiting of EU citizens' right to buy agricultural land in CEE Member States, we included the statement: Foreigners should not be allowed to buy land in [COUNTRY].

Regarding scales, variables related to identification were measured on a scale from 1 to 4 (1 - very closelvery important; 4 - not close at all not important at all), while variables measuring attitudes have a scale from 1 to 5 (1 - agree strongly; 5 - disagree strongly) $)^{9}$.

\subsection{Analysis}

The analysis was conducted by means of univariate, bivariate and multivariate statistical procedures. Univariate procedures were used to show distributions of answers on specific questions, means and standard deviations. Bivariate analyses (analysis of variance, t-tests) served the purpose of testing differences between countries $^{10}$. Multivariate analysis entailed linear regression analysis, which was

All categories of scales can be found in the tables in the online Supplement to the article.

10 The analysis of variance (ANOVA) procedure was done by first conducting Levene's test of equality of variances. If the result suggested non-homogenous variances, the Welch test substituted the standard F test, while the Tamhane T2 test was used for post-hoc comparisons between specific groups. If Levene's test indicated homogenous variances, the standard ANOVA F test was conducted, and Scheffe's test was used for post-hoc comparisons. 
used to test the hypothesised model of a transnational cleavage predicting attitudes towards the EU. Statistical analysis was performed in SPSS (version 26).

\section{RESULTS}

\subsection{Differences in support for EU supranationalism in CEE Member States and by voters of the most significant political parties}

CEE Member States considerably differed in terms of support for EU supranationalism. Table 2 presents frequency distributions of attitudes towards the idea that their country should follow EU decisions, even if it does not agree with them. Data shows that, in most of the analysed countries, nearly a double percentage of respondents disagree (categories 4 and 5) compared to those who agree (categories 1 and 2) with the mentioned idea. The exceptions are Slovenia and Hungary. In Slovenia, equal numbers agree and disagree with this idea. In Hungary, twice as many respondents agree than disagree. The mean values show that Hungarians are the most permissive towards this idea, while Slovenes are neutral. Respondents from all other countries achieve values below the theoretical scale mean. Latvians and Czechs are the most critical of the idea, Croats are slightly less critical than them, and Lithuanians and Estonians are slightly less critical than Croats. ${ }^{11}$ Czechs had been under the influence of pronounced Euroscepticism by their former prime-minister and president Václav Klaus for almost two decades at the time when the survey was conducted (Havlík, Hloušek and Kaniok, 2017). In Latvia, the EU conditionality regarding the protection of the rights of the Russian-speaking minority challenged the Latvian nation-building process, which was based on the domination of ethnic Latvians. This tension was more pronounced in Latvia than in Estonia, which went through a very similar process (Schulze, 2018). The question of following EU decisions in the Latvian and Estonian cases most probably refers to the Russian minority question, as Baltic Russian respondents agreed to a greater extent than ethnic Estonian or Latvian respondents that Latvia or Estonia should follow EU decisions, even if it disagrees with them. On other questions related to EU issues (benefits from being a member of the EU, leaving the EU) Baltic Russian respondents were more Eurosceptic than ethnic Estonian or Latvian respondents. ${ }^{12}$

11 While we do not discuss in detail all the statistically significant differences between the analysed countries, the results of ANOVA and post-hoc tests are presented in tables.

12 Russians constitute $32 \%$ of the Latvian and $25 \%$ of the Estonian sample. Estonian Russians show higher support for supranationalism $(M=2.74 ; S D=1.06)$ than ethnic Estonians $(M=3.42 ; S D=1.31$; $\left.\mathrm{t}_{(351.7)}=7.15 ; \mathrm{p}<0.01\right)$, as is the case for Latvian Russians $(\mathrm{M}=3.31 ; \mathrm{SD}=1.1)$ compared to ethnic Latvians $\left(\mathrm{M}=3.59 ; \mathrm{SD}=0.95 ; \mathrm{t}_{(550.1)}=3.77 ; \mathrm{p}<0.01\right)$. 
Díez Medrano (2020: 74) showed that the average for all EU Member States participating in this ISSP module is $31 \%$ of respondents who "agree or strongly agree that the country should abide by EU decisions even when their own country disagrees", therefore only Hungary and Slovenia had an above-average share of "supranationalists". These results are surprising only from the perspective of Hungary's and Slovenia's ruling parties challenging supranationalism and democratic norms in the beginning of 2020s. Hungary and Slovenia have been the frontrunners of the EU accession process since the late 1990s.

Table 2. (Country) should follow EU decisions, even if it does not agree with them

\begin{tabular}{|c|c|c|c|c|c|c|c|}
\hline (in \%) & $\mathrm{HR}$ & $\mathrm{CZ}$ & EE & $\mathrm{HU}$ & LV & LIT & SI \\
\hline 1 - Agree strongly & 4.3 & 3.5 & 8.8 & 6.8 & 1.8 & 1.2 & 2.9 \\
\hline 2 - Agree & 19.7 & 17.6 & 19.0 & 32.1 & 17.4 & 22.1 & 32.0 \\
\hline 3 - Neither agree nor disagree & 25.6 & 29.6 & 29.8 & 39.7 & 26.1 & 34.8 & 27.9 \\
\hline 4 - Disagree & 35.4 & 30.2 & 26.8 & 14.4 & 38.6 & 36.2 & 31.3 \\
\hline 5 - Strongly disagree & 15.0 & 19.2 & 15.7 & 7.1 & 16.1 & 5.8 & 5.9 \\
\hline M & 3.37 & 3.44 & 3.22 & 2.83 & 3.50 & 3.23 & 3.05 \\
\hline (SD) & $(1.09)$ & $(1.09)$ & $(1.18)$ & $(.996)$ & (1.01) & $(.899)$ & $(.992)$ \\
\hline $\mathrm{F}^{*}$ & \multicolumn{7}{|c|}{$49.877^{* * *}$} \\
\hline Post Hoc & \multicolumn{7}{|c|}{$\begin{array}{l}\text { HR } \neq \text { HU, LIT, SI; CZ } \neq \text { EE, HU, LIT, SI ; EE } \neq \text { CZ, HU, LV } \\
\text { SI; HU } \neq \text { HR, CZ, EE, LV, LIT, SI ; LV } \neq \mathrm{EE}, \mathrm{HU}, \mathrm{LIT}, \mathrm{SI} \\
\text { LT } \neq \mathrm{HR}, \mathrm{CZ}, \mathrm{HU}, \mathrm{LV}, \mathrm{SI} ; \mathrm{SI} \neq \mathrm{HR}, \mathrm{CZ}, \mathrm{EE}, \mathrm{HU}, \mathrm{LV}, \mathrm{LIT}\end{array}$} \\
\hline
\end{tabular}

Despite the rise of right-wing Euroscepticism in the region, the comparison of support for leaving the EU in 2013 with more recent surveys reveals that the percentage of those who support leaving the EU was reduced in all the countries (Table 3 ). The contours of country differences in levels of support have remained, however. Czechs are still the most inclined to support leaving the EU and are likewise the least enthusiastic about remaining in it. Conversely, Lithuanians remained the most supportive of their country's EU membership. Hungary, as the country that has been at the forefront of conflicts with the EU, has not demonstrated a trend towards lower or simply low popular support for its membership. This trend was probably also influenced by a bounce-back from post-economic-crisis dissatisfaction with the EU and the Brexit vote, which made the option of leaving the EU less attractive all over the continent (see De Vries, 2017). In the Baltic countries, the 
Russo-Ukrainian War could have also played a part in lowering the levels of hard Euroscepticism.

Table 3. Leaving vs. remaining in the EU as compared between ISSP 2013 and Spring Eurobarometer 2019

\begin{tabular}{ccc|cc|cc|cc}
\hline & \multicolumn{4}{c}{ ISSP 2013} & \multicolumn{2}{c}{ Spring Eurobarometer 2019 } \\
\cline { 2 - 10 } & \multicolumn{2}{c|}{ Leave } & \multicolumn{2}{c|}{ Remain } & \multicolumn{2}{c}{ Leave } & \multicolumn{2}{c}{ Remain } \\
\cline { 2 - 10 } & $\mathrm{f}$ & $\%$ & $\mathrm{f}$ & $\%$ & $\mathrm{f}$ & $\%$ & $\mathrm{f}$ & $\%$ \\
\hline $\mathrm{CZ}$ & 892 & 46.7 & 735 & 38.5 & 240 & 23.7 & 454 & 44.9 \\
\hline $\mathrm{EE}$ & 289 & 28.6 & 588 & 58.2 & 97 & 9.6 & 715 & 70.7 \\
\hline $\mathrm{HR}$ & 329 & 32.9 & 487 & 48.7 & 168 & 16.7 & 517 & 51.3 \\
\hline $\mathrm{HU}$ & 173 & 17.2 & 558 & 55.5 & 157 & 14.8 & 669 & 63.1 \\
\hline LIT & 132 & 11.1 & 762 & 63.8 & 91 & 9.1 & 702 & 70.2 \\
\hline LV & 394 & 39.4 & 432 & 43.2 & 143 & 14.2 & 612 & 60.9 \\
\hline SI & 258 & 25.5 & 485 & 48.0 & 139 & 13.5 & 728 & 70.5 \\
\hline
\end{tabular}

We will now illustrate instances of possible cue-taking in some countries i.e., whether voters have similar opinions towards the EU as the parties they voted for in the last election. Table 4 presents the most relevant parties at the time this ISSP module was conducted ${ }^{13}$. Along with the mean country results and standard deviations, we also show the scores of voters of specific parties, as well as the parties' general positions towards the $\mathrm{EU}^{14}$. In Croatia and Hungary, the situation was quite clear, as centre-left parties, as well as their voters, were more favourable towards the EU than centre-right parties and their voters. In the Czech case, on the other hand, leftist party voters were more Eurosceptic. In general, the numbers show a higher political elite preference ${ }^{15}$ towards the European project as the position of most of the listed parties towards the EU was a supportive one. A notable exception to this was Fidesz, which became the vanguard of ruling CEE Euroscepticism.

13 Only those parties for whom 100 or more respondents had voted are included.

14 Party EU position scores were sourced from the Chapel Hill Expert Survey 2014 (Polk et al., 2017).

15 Party position scores mostly hover around 6, which is close to the top score (7). To be sure, the two variables compared are not identical. Party preferences estimate the general view of the EU, while the ISSP variable deals with EU supranationalism. Yet in the case of citizens, country means show slightly more disagreement with EU supranationalism than agreement. 
Table 4. Comparison between party voters' attitudes towards following the decisions of the EU and the parties' general positions regarding the EU $(N>100)$.

\begin{tabular}{|c|c|c|c|c|c|c|}
\hline Country & $\begin{array}{l}\text { Country } \\
M(S D)\end{array}$ & Party & $\begin{array}{l}\text { Party voters' } \\
\qquad M(S D)^{1}\end{array}$ & Diff. & $\mathrm{N}$ & $\begin{array}{c}\text { Party } \\
\text { EU_position } \\
(2014)^{2}\end{array}$ \\
\hline \multirow{4}{*}{$\mathrm{CZ}$} & \multirow{4}{*}{$\begin{array}{c}3.44 \\
(1.091)\end{array}$} & ČSSD & $3.47(1.091)$ & \multirow{4}{*}{$\begin{array}{l}\text { ČSSD } \neq \text { KSČM } \\
\text { ČSSD } \neq \text { TOP } 09 \\
\text { KSČM } \neq \text { TOP } 09 \\
\text { KSČM } \neq \text { ANO }\end{array}$} & 326 & 6.07 \\
\hline & & ANO & 3.39 (1.051) & & 262 & 5.20 \\
\hline & & KSČM & $3.81(1.062)$ & & 153 & 2.73 \\
\hline & & TOP 09 & $3.10(1.029)$ & & 104 & 6.67 \\
\hline \multirow{3}{*}{ EE } & \multirow{3}{*}{$\begin{array}{c}3.22 \\
(1.179)\end{array}$} & ER & $3.42(0.992)$ & \multirow{3}{*}{-} & 113 & 6.88 \\
\hline & & EK & 3.06 (1.299) & & 111 & 5.00 \\
\hline & & IRL & $3.27(1.051)$ & & 113 & 6.50 \\
\hline \multirow{2}{*}{$\mathrm{HR}$} & 3.37 & SDP & 3.09 (1.145) & \multirow{2}{*}{$\mathrm{SDP} \neq \mathrm{HDZ}$} & 143 & 6.56 \\
\hline & $(1.089)$ & HDZ & $3.56(1.047)$ & & 133 & 6.22 \\
\hline \multirow{2}{*}{$\mathrm{HU}$} & 2.83 & Fidesz-KNDP & $2.88(0.962)$ & \multirow{2}{*}{$\begin{array}{c}\text { Fidesz-KNDP } \neq \\
\text { MSZP }\end{array}$} & 317 & 2.71 \\
\hline & $(0.996)$ & MSZP & $2.30(0.918)$ & & 113 & 6.07 \\
\hline \multirow{2}{*}{ LIT } & 3.23 & LSDP & $3.20(0.860)$ & \multirow{2}{*}{-} & 185 & 6.60 \\
\hline & $(0.899)$ & DP & $3.19(0.948)$ & & 133 & 5.13 \\
\hline \multirow{2}{*}{ LV } & 3.50 & Unity & $3.55(1.014)$ & \multirow{2}{*}{-} & 109 & 6.80 \\
\hline & $(1.014)$ & Harmony & $3.41(1.091)$ & & 104 & 6.86 \\
\hline \multirow{2}{*}{ SI } & 3.05 & SD & $2.85(1.011)$ & & 111 & 5.85 \\
\hline & $(0.992)$ & SDS & $2.96(0.942)$ & & 109 & 6.38 \\
\hline
\end{tabular}

${ }^{1}$ Country should follow EU decisions. Scale: 1 - agree strongly, 5 - disagree strongly.

${ }^{2}$ Party EU position scale: 1 = least favourable towards the EU, 7 = most favourable towards the EU

There are also some interesting discrepancies between certain parties and their voters. The dominant pattern is that of voters being more Eurosceptical than their parties. In the Czech case, we thus see that social-democrat ČSSD voters were moderately sceptical towards following the decisions of the EU, even though their party was judged to be markedly pro-EU. The very same conclusion applies to the liberal Eesti Reformierakond party (ER) in Estonia and its voters, the Christian Democrat HDZ party in Croatia and the liberal-conservative Unity party in Latvia. ER had elements of soft Euroscepticism during the 1990s, which it later aban- 
doned (Ploom and Veebel, 2017). HDZ transformed itself, during the 2000s, from an internationally isolated nationalistic party of the late 1990s to a pro-European party with strong backing from the European People's Party.

A notable departure from this pattern can be observed in Hungary, where voters of Viktor Orbán's Eurosceptic and conservative Fidesz party, on average, showed a much more favourable attitude towards following EU decisions than the party. Fidesz was originally a pro-EU party, became engaged in soft 'national-interest' Euroscepticism at the beginning of the 2000s and made an explicit turn towards Euroscepticism in 2010 (Taggart and Szczerbiak, 2001: 18; Csehi and Zgut, 2021: $63)$. This indicates that, in these, cases voters were rather slow in taking cues on the EU from the parties they supported. These results corroborate Taggart and Szczerbiak's (2004) conclusion that, in some CEE candidate countries, the level of party-based Euroscepticism did not correlate to levels of popular Euroscepticism (they showed that Hungary had low public Euroscepticism, but high party-based Euroscepticism). Croatia, as these results also indicate, was an opposite case. The comparison of results in Hungary and Croatia also indicates the difference between the two countries mentioned in the theoretical-conceptual framework. Although in both countries a transnational cleavage between the voters of the two main parties could be discerned, only in Hungary does this cleavage seem to be clearly politicised.

\subsection{Respondents' identities and attitudes towards their nation and Europe}

The mean values of variables we explore as predictors of the attitude towards EU supranationalism are shown in Table 5 and are presented in detail in the online Supplement. When looking at absolute values as they relate to the theoretical scale mean, we can infer that citizens tend to feel closer to their countries than towards Europe in all of the cases. The difference is least pronounced in Central European states (Hungary and the Czech Republic), but is particularly pronounced in the Baltic states - Estonia, Latvia and, to a lesser degree, Lithuania, as well as in the former Yugoslav states Croatia and Slovenia, which also show a notable discrepancy. Czechs and Hungarians also profess noticeably higher closeness to Europe than others do.

The four variables pertaining to two dimensions of nationalism, in general, reveal a higher preference for aspects of civic identity, rather than ethnic ones. Having country citizenship and respecting political institutions and laws tends to be deemed more important for being a true national than belonging to the dominant religion or having dominant ethnic group ancestry. 


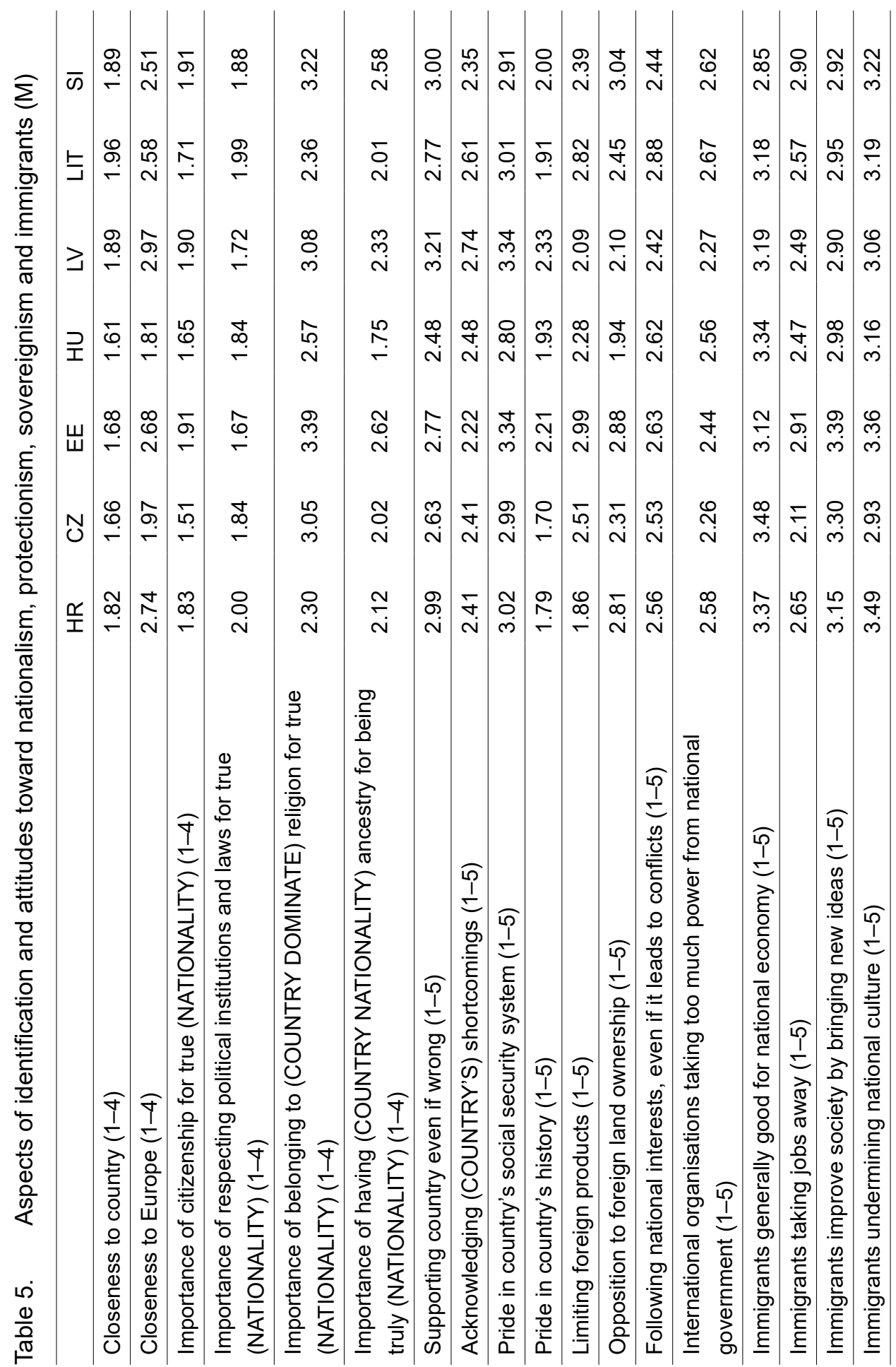


Religion, in particular, was shunned in the non-religious Czech Republic and Estonia, as expected, but surprisingly the same also happened in Slovenia and Latvia. Religious affiliation as a part of national identity is most important to respondents from Croatia and Lithuania, where Catholicism is the dominant religion and Catholic Church was an important protector of national identity during communism. Ancestry, on the other hand, was overall considered more important than religion, with Hungary standing out with a mean value close to those of the variables representing civic nationalism.

On the whole, the two variables covering nationalism point to a mixed bag of results. Respondents in all countries are somewhat on the fence regarding supporting their own country even if it is wrong, but Czechs, Estonians, Hungarians and Lithuanians lean towards it more than the others. We cannot observe the same constellation with answers about acknowledging a country's shortcomings, but this time around there is more inclination towards agreement with the hypothetical in all the countries.

The results for the two explored aspects of national pride should be interpreted carefully. Pride in a country's social security system may be tied to overall satisfaction with the quality of governance, which tends to be lower in CEE. Even if these countries still carry elements of a more socially oriented approach to services, this is not something they tend to, on average, highly link to national pride. On the flipside, respondents in all countries stated greater pride in national history, which was the highest in Croatia and the Czech Republic, and the lowest in Estonia.

Regarding protectionism, the means point to rather stark differences between some countries. Estonians were the least protectionist on both variables, reflecting the neoliberal policies which have been pursued there since the 1990s. On the other hand, Croats heavily favoured limiting the import of foreign products, as even during the accession process "Buy Croatian" campaigns were led. The same goes for opposing foreign land ownership. Hungarians are, on average, distinctly inclined to oppose foreign land ownership, all the while Slovenians are much laxer about the prospect.

With sovereignism, we default back to less pronounced country differences. In all of the countries, more respondents agree than disagree with following national interests even if they lead to conflict. Likewise, most are of the opinion that international organisations take too much power away from their own government.

Finally, citizens of CEE states had a somewhat negative attitude towards immigrants as an economic threat even prior to the politicisation of migration. Only Slovenes slightly leaned towards thinking that immigrants might be good for their country's economy, but were also slightly more in agreement than in disagreement 
with the idea that immigrants are taking jobs away. Even if attitudes towards immigrants were not exceptionally positive, it should be noted that the idea of some sort of a cultural danger was not supported at that time. Respondents were apprehensive about immigrants improving society by bringing new ideas and did express doubts about them undermining national culture, but the mean values do not show great deviation from the theoretical scale mean.

\subsection{Effects of sociodemographic characteristics, identities and attitudes of respondents on their attitude towards EU supranationalism}

We conducted regression analyses to determine whether the sociodemographic characteristics, identities and attitudes of respondents are related to positive or negative attitudes toward their country following the decisions of the EU even if it does not agree with them. The first regression model tested the effects of sociodemographic variables and the second one tested the effects of variables representing different aspects of respondents' identification and attitudes.

The results presented in Table 6 show that the sociodemographic characteristics included in Model 1 explain 1.5-4.4\% of the variance of the dependent variable in most of the analysed countries. However, in Croatia, none of the sociodemographic variables significantly affects the attitude of respondents on EU supranationalism. We assume that the reason for this lies in the fact that dominant public and political narratives presented EU accession as "Croatia's escape from the Balkans" i.e. as a necessary step, which during the long accession process lost its emotional dimension and resulted in euro-indifferentism (Jović, 2012). ${ }^{16}$ In other countries, gender, age, socioeconomic status, place of residence (urban-rural) and frequency of attending religious services have been shown to influence respondents' attitudes about whether their country should follow EU decisions even if it does not agree with them. For example, in Slovenia, women and those who attend religious ceremonies more often are more likely to agree with EU supranationalism than men and those who attend religious ceremonies less often. In the Czech Republic, EU supranationalism is more supported by younger respondents, those who attend religious services more frequently, those who live in larger urban areas and those of higher socioeconomic status. In Latvia and Lithuania, EU supranationalism is also more supported by younger respondents and those who attend religious services more frequently. In addition, in Lithuania, EU supranationalism

16 At the time this survey was conducted Croatia had been a member of the EU for just a year. Therefore, it could be that the effect of the mentioned narrative "outweighed" the effects of the sociodemographic differences among people. 
is more supported by those who "place themselves" in higher socioeconomic positions. In Estonia, EU supranationalism is more supported by respondents who live in larger settlements than those who live in smaller settlements. The model showed that the respondents from Hungary differ to some extent from the previous cases. Namely, in that country, EU supranationalism is more supported by those who attend religious services less often and those with a higher level of education. These differences regarding religion coincide with national political contexts. ${ }^{17}$ In Hungary, Socialist voters are less religious than Fidesz voters and more pro-EU. ${ }^{18}$ Hungary showed consistent and reinforcing social divisions compared to other CEE countries, which became particularly visible during the early 2000s in conflicts between Fidesz and socialists over the definition of the Hungarian nation, in which socialists were deemed as traitors (Gessler and Kyriazi, 2019). In Latvia, on the other hand, the Russian minority is on average more religious and more supportive of the EU imposing its decisions on the country. ${ }^{19}$ In the Czech Republic, Communist Party (KSČM) voters, as already mentioned, show a more critical attitude towards EU supranationalism and, on average, very rarely attend religious services while the opposite is true for Christian Democratic Party (KDU-ČSL) voters. ${ }^{20}$

17 Besides, respondents from smaller settlements show more support for EU supranationalism, but we believe this to be a case of suppression (zero-order correlation is close to zero and not significant).

18 Fidesz voters' $(M=6.20 ; S D=1.88)$ attend religious services more often than Socialist voters $\left(\mathrm{M}=6.61 ; \mathrm{SD}=1.64 ; \mathrm{t}_{(482)}=2.23 ; \mathrm{p}<0.01\right)$.

19 Latvian Russians $(M=5.91 ; S D=1.75)$ attend religious services more often than ethnic Latvians $(\mathrm{M}=6.35 ; \mathrm{SD}=1.77 ; \mathrm{t}(933)=3.59 ; \mathrm{p}<0.01)$.

20 KSČM voters' attendance of religious services is by far lower $(M=7.12 ; S D=1.34)$ than that of KDUČSL voters $\left(M=4.53 ; \mathrm{SD}=1.64 ; \mathrm{t}_{(90.8)}=-8.87 ; \mathrm{p}<0.01\right)$. 
Table 6. Regression analysis - the effect of sociodemographic characteristics on attitude toward Country following EU decision (even if it does not agree with them)

\begin{tabular}{llllllll}
\hline HR & CZ & EE & HU & LV & LIT & SI
\end{tabular}

Stand. $\beta$ Stand. $\beta$ Stand. $\beta$ Stand. $\beta$ Stand. $\beta$ Stand. $\beta$ Stand. $\beta$

\begin{tabular}{lccccccc}
\hline Sex of Respondent & .031 & -.013 & -.005 & -.001 & -.012 & .029 & $.122^{* * *}$ \\
\hline Age of respondent & -.049 & $.054^{*}$ & -.014 & -.014 & $.158^{* * *}$ & $.078^{*}$ & .003 \\
\hline $\begin{array}{l}\text { Highest completed } \\
\text { education level }\end{array}$ & .006 & .007 & -.001 & $-.210^{* *}$ & -.031 & -.031 & -.030 \\
\hline $\begin{array}{l}\text { Attendance of } \\
\text { religious services }\end{array}$ & -.035 & $.060^{*}$ & -.015 & $-.082^{*}$ & $.099^{*}$ & $.074^{*}$ & $.082^{*}$ \\
\hline $\begin{array}{l}\text { Top-bottom self- } \\
\text { placement }\end{array}$ & -.044 & $-.139^{* * *}$ & -.060 & -.044 & .023 & $-.148^{* * *}$ & -.058 \\
\hline $\begin{array}{l}\text { Did respondent vote in } \\
\text { last general election }\end{array}$ & .060 & -.025 & -.003 & -.008 & -.043 & .013 & -.004 \\
\hline $\begin{array}{l}\text { Place of living: urban- } \\
\text { rural }\end{array}$ & .058 & $.095^{* * *}$ & $.209^{* * *}$ & $-.085^{*}$ & .037 & -.023 & .048 \\
\hline Adjusted R ${ }^{2}$ & .005 & .032 & .042 & .044 & .028 & .030 & .015 \\
\hline $\mathrm{F}$ & 1.509 & 9.198 & 5.50 & 6.205 & 3.966 & 5.202 & 2.716 \\
$\mathrm{p}$ & $\mathrm{p}<.161$ & $\mathrm{p}<.000$ & $\mathrm{p}<.000$ & $\mathrm{p}<.000$ & $\mathrm{p}<.000$ & $\mathrm{p}<.000$ & $\mathrm{p}<.009$ \\
\hline
\end{tabular}

${ }^{1}$ Categories for international comparison.

The results presented in Table 7 show that predictors included in Model 2 explain a higher percentage of the variance of the dependent variable (between 8-22.4\%) than predictors from Model 1. It can also be observed that variables representing respondents' attitudes towards nationalism, protectionism, sovereignism and immigrants are more frequent predictors of the dependent variable than variables representing discussed deeper issues of contention between Eastern and Western Europe i.e., different aspects of respondents' identification. 


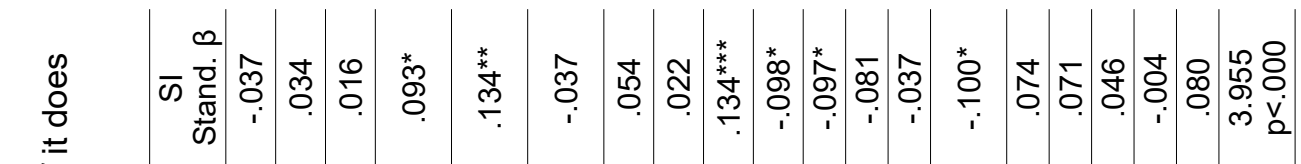

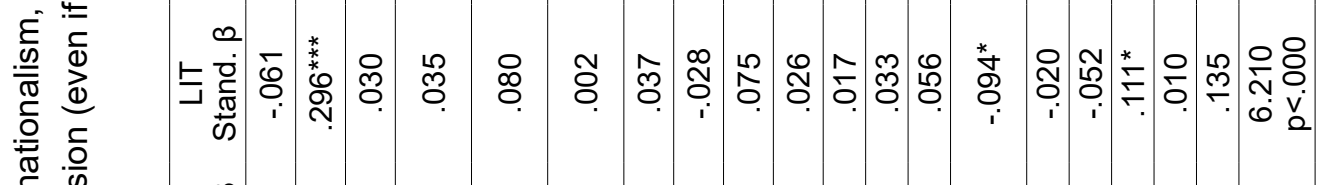

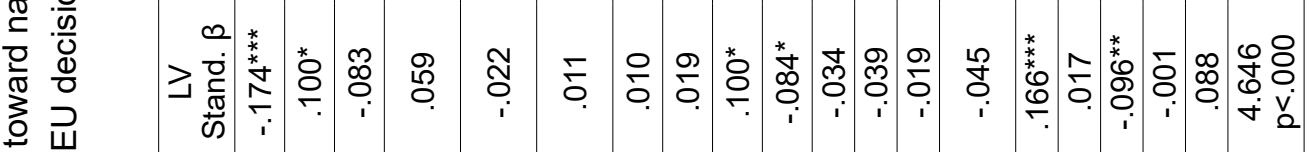
彭产

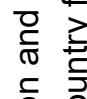

s

它 至

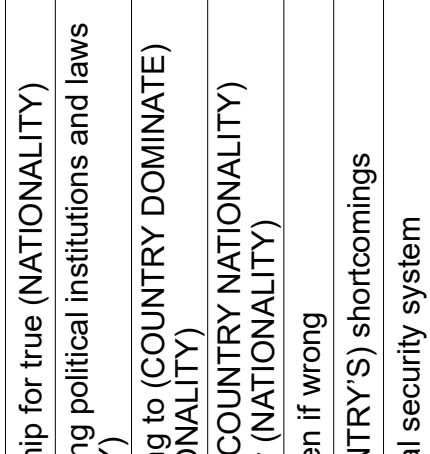


For example, only the variable that measures the feeling of closeness to Europe proves to be a statistically significant predictor of the dependent variable in most of the analysed countries. Those who feel closer to Europe are more willing to accept the idea that their country should follow EU decisions. Exceptions are the Czech Republic and Slovenia, where this is not the case. Furthermore, in Latvia, respondents who feel closer to their country are more inclined to reject the idea that their country should unquestioningly follow EU decisions. In addition, in Estonia and Slovenia, those for whom religious affiliation is a more important aspect of national identity are more supportive of EU supranationalism. Finally, in Slovenia, those who feel it is important to respect the country's political institutions and laws are also more supportive of EU supranationalism.

On the other hand, as expected, attitudes towards sovereignism prove significant for accepting or rejecting EU supranationalism. In all countries except Latvia, respondents who feel that international organisations are taking too much power from nation-states do not support EU supranationalism. Similarly, in Croatia, the Czech Republic and Hungary, this idea is more likely to be rejected by respondents who believe that the country should pursue its interests even when it leads to conflict. Aspects of national pride have been significant predictors of the dependent variable in some countries. In most countries, with the exception of Hungary and Lithuania, respondents who are less proud of their country's social security system are also less supportive of EU supranationalism. This possibly reflects the fact that those less proud of their country's social security system are also less well off. In contrast, in the Czech Republic, Latvia and Slovenia, respondents who are prouder of their country's history are less supportive of EU supranationalism. Attitudes towards protectionism also proved to be statistically significant predictors in Croatia, the Czech Republic and Slovenia. Croats and Czechs who believe that foreigners should not be allowed to buy land in their countries are more likely to disagree with EU supranationalism, as are Czechs and Slovenes who believe that their governments should restrict imports of products from other countries to protect their economies. For most of these cases, possible explanations could be looked up in the structures of their economies and the dangers that part of the public sees in less protectionist economic policies and more Europeanised economies for future economic development. The Croatian economy is reliant on tourism dominated by private renters. Slovenia was able to protect numerous companies from foreign takeover during the transition to capitalism and the Czech Republic has the strongest industrial tradition in CEE.

Attitudes related to nationalism are connected with dependent variables in Croatia, the Czech Republic and Hungary. Quite unexpectedly, it turns out that Croats and Czechs who believe that people should support their country even when it is 
wrong tend to accept the idea that their country should follow EU decisions even when it disagrees with them. A possible explanation could be discerned from the fact that HDZ voters have these characteristics. HDZ was responsible for cooperation with Hague, which resulted in EU accession, but also often espoused strong nationalistic and anti-Hague sentiments. At the same time, in Hungary, people who disagree with this claim are, as expectedly, more supportive of EU supranationalism. Similarly, Czechs and Hungarians who agree with the idea that the world would be a better place if the citizens of a country were aware of its shortcomings, are also more inclined to support EU supranationalism.

Finally, attitudes towards immigrants are linked to support for EU supranationalism. In most countries, with the exception of Estonia and Slovenia, respondents who agree with the idea that immigrants can improve society by bringing new ideas and culture are also more willing to agree with EU supranationalism. In Latvia, on the other hand, those who are more pro-immigrant in terms of culture are less supportive of EU supranationalism. However, due to a low and positive zero-order correlation, we believe this to be a case of suppression. EU supranationalism is also more likely to be supported by those Czechs, Hungarians and Latvians who believe that the arrival of immigrants is generally good for the country's economy.

Interestingly, those Estonians who believe that immigrants take jobs from their fellow citizens are also inclined to support EU supranationalism. Ethnic Estonians mostly produce this unusual correlation as some of them probably equated pro-Europeanism with anti-Russian stances i.e., they saw the EU as an exit from Russian imperial ambitions and colonisation and still see the Russian minority as immigrants (on anti-immigrant foundations of Estonian nationalism, see Smith, 2003). In addition, Estonian Russians are overall more concerned with immigrants taking jobs away and are more willing to accept EU decisions. ${ }^{21}$ This is most likely connected to their positive assessment of the EU conditioning Estonian accession with the protection of minority rights. In contrast, Hungarians who believe that immigrants take jobs from their fellow citizens tend to reject EU supranationalism. The claim that immigrants undermine the culture of the country of arrival has not proved to be significantly related to the dependent variable in any of the analysed countries. This could be related to the fact that the narratives which oppose the acceptance of immigrants on the basis of "defending the values of Christian Europe" have become prominent in public and political debates only after the start of the migration crisis.

21 Ethnic Estonians ( $M=3.02 ; S D=1.04)$ less often think that immigrants take job away than Estonian Russians $\left(\mathrm{M}=2.65 ; \mathrm{SD}=1.21 ; \mathrm{t}_{(370.2)}=4.12 ; \mathrm{p}<0.01\right)$. 


\section{DISCUSSION AND CONCLUSION}

Even though general explanations of the public support for the EU exist, our research showed that national contexts matter a great deal. Higher social status, higher education level and living in urban areas are associated with higher support for EU supranationalism confirming the utilitarian approach, but only in some of the analysed countries. The seven countries we analysed showed a non-negligible discrepancy between levels of support and between the predictors of support. Aside from country differences we also found perplexing relations between politics and the public. The Hungarian case perhaps best exemplifies the complexity of the issue. The citizens of the country that has been at the forefront of CEE conflicts with the EU have in fact shown the greatest support for following the decisions of Brussels. On the other hand, our regression model was most successful in Hungary i.e., it explained the highest share of variability. This is because, despite being generally pro-EU, questions of nationalism, sovereignism and immigration correlated with Hungarian respondents' attitudes towards the EU even before the migrant crisis, probably reflecting an earlier emergence of transnational cleavage in Hungary. At the same time, questions of national identity, religion and history were not significant predictors. This points to the salience of broader sovereigntist sentiments in public opinion (as in most analysed countries), but also indicates that political elites can build on existing cleavages by further politicising them.

When looking at national identity in other CEE countries, we found that neither the ethnic nor the civic aspects of national identity proved to be correlated with support for following EU decisions in most of the cases. We cannot espouse a similar conclusion concerning immigration since we observed that positively worded statements about immigration were in most cases positively correlated with support for following the decisions of Brussels. It is, however, worthy of mention that the statement about the cultural threat posed by immigration did not predict opposition to EU supranationalism. Furthermore, the data show that in all of the analysed countries public opinion was somewhat more concerned with negative economic consequences than with negative cultural consequences of migration. This was contrary to the emphasis political elites placed on the cultural threat during and after the migration crisis. This could add weight to the hypothesis of political elites constructing the narrative of the crisis.

The question of CEE seeing itself as somehow truer to Christianity, which would oppose it to the West and the EU, did not have much grounding in 2013. In fact, this paper points to quite the opposite. In Slovenia and Estonia, seeing religion as part of national identity was positively correlated with support for the EU. Moreover, in 4 of the 5 countries where church attendance predicted support for following the 
decisions of the EU, the more frequent churchgoers tended to be more in favour of the EU, which corresponds to previous research (see Nelsen and Guth, 2005). The only exception was Hungary, which may yet again point to some fertile ground for Orbán's narratives. Even though history is present as a point of contention between CEE and the EU in some narratives, this study finds that citizens of most of the analysed countries did not recognise it as such. However, pride in national history was negatively correlated with the support for EU supranationalism in three countries: the Czech Republic, Latvia and Slovenia.

We also noticed that, in almost all of the countries, being proud of the country's social system was a significant predictor. That could point to citizens' support for following EU decisions being related to their position in social stratification. As indicated in the results of effects of sociodemographic characteristics, those who see themselves as having a higher status are more likely to support EU supranationalism. Likewise, those who have suffered the most from transition and Europeanisation costs are probably more likely to be critical of their country's social security system and oppose EU supranationalism.

The results indicate that different accession processes and EU conditionality could have left quite a strong mark on the opinion on the EU, particularly when they also questioned nation-state identities. In Latvia and Estonia, EU conditionality has different meanings for titular nations and Baltic Russians. In Croatia, it could have produced a relatively broad sense of seeing the EU only as a necessity for escaping the Balkans. Regarding the answer to the question of whether the CEE-Brussels rift came from below or above, it seems that elites are able to bypass public opinions and construct an anti-EU climate, however not out of thin air. The conditions for such a process were clearly present in Hungary and this calls for further analysis of cleavages and their politicisation by prominent ideological entrepreneurs.

The impact of political elites can hardly be overstated and Fidesz's anti-EU and anti-immigrant campaigns were crucial in creating the CEE-Brussels rift. However, the Hungarian case also suggests that following the predictors of opposition to EU supranationalism can indicate polarisation in a given society and help predict its transposition at a European level. When compared to other analysed CEE countries, the Hungarian public has to the highest extent formed its opposition and support to EU supranationalism according to the theory of transnational cleavage. Only the Czech Republic comes close to it and that is due to its preoccupation with protectionism, probably reflecting the importance of the socioeconomic cleavage. A brief historical comparison with all other analysed countries shows that they all (except Hungary and, with some caveat, the Czech Republic) started their transition with issues of gaining statehood looming large. Hungarian and Czech elites 
could focus on other social issues and potential contentions from the start of the transition, whereas elites in other countries for quite some time saw the EU primarily as a "rescue" of their newly founded nation-states (Milward, 2019).

Finally, we want to point to the limitations of this paper. Some questions likely carry different meanings in different countries. Regarding immigration, different ethnic groups could be considered immigrants prior to the migration crisis, for instance, in the cases of Latvia and Estonia and their relations toward Russians. Another limitation is that we focused exclusively on the issue of following the decisions of the Union, which means that the research should not be interpreted as exploring general attitudes towards the EU. Future research should further investigate this topic and explain the similarities and/or differences between countries, as well as similarities and differences between the political elites and the public in identification and attitudes related to support for the EU.

\section{FUNDING}

This paper was written as part of the "Integration and Disintegration of the European Union: Dynamics of Europeanism and Euroscepticism" project supported by the Croatian Science Foundation under Grant UIP-2019-04-2979.

\section{CONFLICT OF INTEREST}

Authors declare no conflict of interest.

\section{ETHICAL APPROVAL}

Not applicable [secondary analysis of publicly available data].

\section{DATA ACCESS AND TRANSPARENCY}

Data available from the GESIS data archive:

ISSP (2015). International Social Survey Programme: National Identity - ISSP 2013. Cologne: GESIS Data Archive. Data File Version 2.0.0. https://doi. org/10.4232/1.12312

Analytic procedures in SPSS and additional analyses available from the online Supplement to this article (https://hrcak.srce.hr/ojs/index.php/rzs/libraryFiles/ downloadPublic/233). 


\section{REFERENCES}

Arató K and Koller B (2018). Hungary in the Visegrád Group. In: Schweiger C and Visvizi A (eds). Central and Eastern Europe in the EU: Challenges and Perspectives Under Crisis Conditions. Abingdon: Routledge, 90-105. https://doi.org/10.4324/9781315230986-7

Bago M (2011) Ekskluzivno: Nakon presude generalima dramatično pala potpora ulasku u EU. Dnevnik.hr 16 April https://dnevnik.hr/vijesti/hrvatska/nakon-presude-generalimadramaticno-pala-potpora-ulasku-u-eu.html (16 December 2021)

Bakker R, Hooghe L, Jolly S, Marks G, Polk J, Rovny J, Steenbergen M and Vachudova MA (2020). 2019 Chapel Hill Expert Survey. Version 2019.1.. Chapel Hill, NC: University of North Carolina. https://www.chesdata.eu/2019-chapel-hill-expert-survey (16 December 2021)

Bandelj N and Gibson CW (2020). Contextualizing Anti-Immigrant Attitudes of East Europeans, Review of European Studies, 12 (3): 32-49. https://doi.org/10.5539/res. v12n3p32

Bíró-Nagy A (2021). Orbán's Political Jackpot: Migration and the Hungarian Electorate, Journal of Ethnic and Migration Studies. Advanced online publication, 9 February. https:// doi.org/10.1080/1369183X.2020.1853905

Csehi R and Zgut E (2021). 'We Won't Let Brussels Dictate Us': Eurosceptic Populism in Hungary and Poland, European Politics and Society, 22 (1): 53-68. https://doi.org/10.1 080/23745118.2020.1717064

De Vries CE (2017). Benchmarking Brexit: How the British Decision to Leave Shapes EU Public Opinion, JCMS: Journal of Common Market Studies, 55 (S1): 38-53. https://doi. org/10.1111/jcms. 12579

Díez Medrano J (2020). National Identity and the Citizens' Europe. In: Duina F and Merand F (eds). Europe's Malaise (Research in Political Sociology Book 27). Bingley:Emerald Publishing Limited, 67-83. https://doi.org/10.1108/S0895-993520200000027007

Enyedi $Z$ (2020). Right-wing authoritarian innovations in Central and Eastern Europe, East European Politics, 36 (3): 363-377. https://doi.org/10.1080/21599165.2020.1787162

Gessler T and Kyriazi A (2019). Hungary - A Hungarian Crisis or Just a Crisis in Hungary? In: Hutter S and Kriesi H (eds). European Party Politics in Times of Crisis (1sted.). Cambridge: Cambridge University Press, 167-188. https://doi.org/10.1017/9781108652780.008

Hamáček J, Helme M, Pintér S, G̦irǵens S, Kamiński M, Mikulec R and Hojs A (2020). Joint Letter by the Ministers of the Interior of the Czech Republic, Estonia, Hungary, Latvia, Poland, Slovakia and Slovenia. https://twitter.com/ADimitrovs/ status/1270698631369297921 (16 December 2021)

Havlík V, Hloušek V and Kaniok P (2017). Europeanised Defiance-Czech Euroscepticism Since 2004. Opladen: Verlag Barbara Budrich. https://doi.org/10.2307/j.ctvdfOh3g

Hloušek V and Kopeček L (2008). Cleavages in the Contemporary Czech and Slovak Politics Between Persistence and Change, East European Politics and Societies: And Cultures, 22 (3): 518-552. https://doi.org/10.1177/0888325408315833

Hobolt SB and de Vries CE (2016). Public Support for European Integration, Annual Review of Political Science, 19 (1): 413-432. https://doi.org/10.1146/annurevpolisci-042214-044157 
Hooghe L and Marks G (2018). Cleavage Theory Meets Europe's Crises: Lipset, Rokkan, and the Transnational Cleavage, Journal of European Public Policy, 25 (1): 109-135. https://doi.org/10.1080/13501763.2017.1310279

ISSP (2015). International Social Survey Programme: National Identity - ISSP 2013. Cologne: GESIS Data Archive. Data File Version 2.0.0. https://doi.org/10.4232/1.12312

Janmaat JG (2006). Popular Conceptions of Nationhood in Old and New European Member States: Partial Support for the Ethnic-Civic Framework, Ethnic and Racial Studies, 29 (1): 50-78. https://doi.org/10.1080/01419870500352363

Jović D (2012). Hrvatski referendum o članstvu u Europskoj uniji i njegove posljedice za smanjeni Zapadni Balkan, Anali Hrvatskog politološkog društva, 9 (1): 163-182.

Joye D and Sapin M (2016). Report to the ISSP General Assembly on monitoring work undertaken for the ISSP by the Methodology Committee. https://dbk.gesis.org/dbksearch/ file.asp?file=ZA5950_mr.pdf (17 November 2021)

Krašovec A and Batrićević N (2020). Cleavages and Government in Slovenia and Montenegro, Politics in Central Europe, 16 (2): 593-621. https://doi.org/10.2478/pce2020-0027

Lavrič M and Bieber F (2021). Shifts in Support for Authoritarianism and Democracy in the Western Balkans, Problems of Post-Communism, 68 (1): 17-26. https://doi.org/10.1080 /10758216.2020.1757468

Márkus G (1999). Hungarian Cleavages and Parties prior to 1989. In: Lawson K, Römmele A and Karasimeonov G (eds). Cleavages, Parties, and Voters. Studies from Bulgaria, the Czech Republic, Hungary, Poland, and Romania. Westport: Praeger, 61-76.

Milward A (1999). The European Rescue of the Nation-state. London: Routledge. https://doi. org/10.4324/9780203982150

Nelsen B and Guth J (2005). Religion and Attitudes toward the European Union: The New Member States European Union Studies Association Ninth Biennial International Conference, 1-14. http://aei.pitt.edu/3053/1/EUSA_2005_1.5.pdf (16 December 2021)

Orbán V (2020). Address by Prime Minister Viktor Orbán at the Inauguration of the Memorial to National Cohesion. About Hungary, August 20. http://abouthungary.hu/speeches-andremarks/address-by-prime-minister-viktor-orban-at-the-inauguration-of-the-memorialto-national-cohesion/ (14 June 2021)

Pauković D and Raos V (2015). Democratic Deficits, Delayed Democratization and Prolonged EU Accession. In: Maldini P and Pauković D (eds). Croatia and the European Union: Changes and Development. Farnham: Ashgate, 33-53.

Petrović N (2019). Divided National Memories and EU Crises: How Eurosceptic Parties Mobilize Historical Narratives, Innovation: The European Journal of Social Science Research, 32 (3): 363-384. https://doi.org/10.1080/13511610.2018.1523710

Ploom I and Veebel V (2017). Emulated Euroskepticism in Estonian Politics. In: Bukovskis K and Austers A (eds). Euroskepticism in the Baltic States: Uncovering Issues, People and Stereotypes. Riga: Latvian Institute of International Affairs and Friedrich Ebert Stiftung, 51-68.

Polk J, Rovny J, Bakker R, Edwards E, Hooghe L, Jolly S, Koedam J, Kostelka F, Marks G, Schumacher G, Steenbergen M, Vachudova MA and Zilovic M (2017). Explaining the Salience of Anti-elitism and Reducing Political Corruption for Political Parties in Europe With the 2014 Chapel Hill Expert Survey dana, Research \& Politics, 4 (1): 1-9. https:// doi.org/10.1177/2053168016686915 
Reeskens T and Hooghe M (2010). Beyond the Civic-Ethnic Dichotomy: Investigating the Structure of Citizenship Concepts Across Thirty-Three Countries, Nations and Nationalism, 16 (4): 579-597. https://doi.org/10.1111/j.1469-8129.2010.00446.x

Santana A, Zagórski P and Rama J (2020). At Odds With Europe: Explaining Populist Radical Right Voting in Central and Eastern Europe, East European Politics, 36 (2): 288-309. https://doi.org/10.1080/21599165.2020.1737523

Schulze JL (2018). Strategic Frames: Europe, Russia, and Minority Inclusion in Estonia and Latvia. Pittsburgh: University of Pittsburgh Press. https://doi.org/10.2307/j.ctt21c4t1f

Sekulić D, Massey G and Hodson R (2006). Ethnic Intolerance and Ethnic Conflict in the Dissolution of Yugoslavia, Ethnic and Racial Studies, 29 (5): 797-827. https://doi. org/10.1080/01419870600814247

Shulman S (2002). Challenging the Civic/Ethnic and West/East Dichotomies in the Study of Nationalism, Comparative Political Studies, 35 (5): 554-585. https://doi. org/10.1177/0010414002035005003

Smith DJ (2003). Minority Rights, Multiculturalism and EU Enlargement: The Case of Estonia, JEMIE - Journal on Ethnopolitics and Minority Issues in Europe, 4 (1): 1-37.

Styczyńska N (2017). Eurosceptic Parties in the Central and Easter European Countries: A Comparative Case Study of Poland, Hungary and Bulgaria. In: Leruth B, Startin N and Usherwood S (eds). The Routledge Handbook of Euroscepticism. London: Routledge, 139-154. https://doi.org/10.4324/9781315464015-14

Taggart P and Szczerbiak A (2001). Parties, Positions and Europe: Euroscepticism in the EU Candidate States of Central and Eastern Europe. Brighton: Sussex European Institute.

Taggart P and Szczerbiak A (2004). Contemporary Euroscepticism in the party systems of the European Union candidate states of Central and Eastern Europe, European Journal of Political Research, 43 (1): 1-27. https://doi.org/10.1111/j.1475-6765.2004.00143.x

Vachudova MA (2005). Europe Undivided: Democracy, Leverage, and Integration After Communism. Oxford: Oxford University Press. https://doi. org/10.1093/0199241198.001.0001

Vachudova MA (2020). Ethnopopulism and Democratic Backsliding in Central Europe, East European Politics, 36 (3): 318-340. https://doi.org/10.1080/21599165.2020.1787163

Zielonka J and Rupnik J (2020). From Revolution to 'Counter-Revolution': Democracy in Central and Eastern Europe 30 Years On, Europe-Asia Studies, 72 (6): 1073-1099. https://doi.org/10.1080/09668136.2020.1784394

Zou D, Lloyd JEV and Baumbusch JL (2019). Using SPSS to Analyze Complex Survey Data: A Primer, Journal of Modern Applied Statistical Methods, 18 (1): 2-22. https://doi. org/10.22237/jmasm/1556670300 


\title{
Otpor EU odozdo ili odozgo? Javno mnijenje u srednjoj i istočnoj Europi prije migracijske krize 2015.
}

\author{
Nikola PETROVIĆ (DD https://orcid.org/0000-0002-0308-521X \\ Institut za društvena istraživanja u Zagrebu - IDIZ, Hrvatska \\ nikola@idi.hr \\ Marko MRAKOVČIĆ (D) https://orcid.org/0000-0002-4919-0277 \\ Pravni fakultet, Sveučilište u Rijeci, Hrvatska \\ mmrakovcic@pravri.hr \\ Filip FILA (D) https://orcid.org/0000-0002-9127-3324 \\ Institut za društvena istraživanja u Zagrebu - IDIZ, Hrvatska \\ filip@idi.hr
}

\section{SAŽETAK}

Odnosi između Bruxellesa i država srednje i istočne Europe pogoršali su se tijekom i nakon migracijske krize iz 2015. godine. Kako bi se ustanovilo koliko su stavovi građana srednje $\mathrm{i}$ istočne Europe pridonijeli i/ili odgovarali tom novom stanju, ovaj rad istražuje javno mnijenje prije migracijske krize u sedam srednje i istočne Europe članica EU-a. Propitujemo mogu li se glavni problemi rascjepa (otpor srednje i istočne Europe političkih elita spram slijeđenja odluka EU-a i spram imigracije te njihov naglasak na suverenizmu, nacionalizmu, kršćanskoj Europi i povijesnim traumama) dovesti u vezu sa stavovima javnosti prema tim problemima prije migracijske krize. Koristili smo National Identity modul ISSP-a koji je proveden 2013. i 2014. u Češkoj, Estoniji, Hrvatskoj, Mađarskoj, Litvi, Latviji i Sloveniji. Rezultati pokazuju da otpor spram EU supranacionalizma nije bio povezan s etničkim nacionalizmom, a ni religijskim identitetom (osim u Mađarskoj). Suprotno naglasku političkih elita na kulturnu prijetnju od migracija, javno mnijenje bilo je više zaokupljeno pitanjem ekonomske prijetnje. Štoviše, percepcija kulturne prijetnje nije bila povezana s otporom EU supranacionalizmu ni u jednoj od država. No, potpora suverenizmu (gotovo u svim državama) i ponos nacionalnom poviješću (u nekim državama) osobito su bile negativno povezane s potporom EU supranacionalizmu. Rezultati sugeriraju da su političke elite mogle zaobići javno mnijenje i konstruirati antiEU atmosferu, iako ne ni iz čega. Uvjeti za takav proces postojali su u Mađarskoj s ondje nastajućim transnacionalnim rascjepom, a to upućuje na važnost proučavanja rascjepa $u$ istraživanju euroskepticizma.

Ključne riječi: euroskepticizam, srednja i istočna Europa, javno mnijenje, nacionalni identitet, migracija 
